\title{
Effects of biochar and barley straw application on the rice productivity and greenhouse gas emissions of paddy field
}

\author{
Se-Won Kang ${ }^{1 \dagger}$, Jin-Ju Yun ${ }^{1 \dagger}$, Jae-Hyuk Park', Yong Hwa Cheong ${ }^{1}$, Jong-Hwan Park², Dong-Cheol Seo ${ }^{3,4^{*}}$ and \\ Ju-Sik Cho ${ }^{1 *}$
}

\begin{abstract}
To improve the agricultural environment, utilization of biochar and organic materials from paddy fields gaining importance. This is because the long-term use of inorganic fertilizers aggravates the soil environment, and also because rice paddy is a major source of $\mathrm{CH}_{4}$ and $\mathrm{N}_{2} \mathrm{O}$ emissions during rice cultivation which involves continuous flooding. Recently, the application of organic materials and biochar to the soil has received increasing attention due to their potential benefits related to soil quality, crop growth, and greenhouse gas emission. This study examines the influence of biochar and straw treatments on rice growth, soil physicochemical properties, and global warming potential in the paddy field. Five treatments were applied for the study: control (Cn), inorganic fertilizer (IF), barley straw biochar $(B C)$, barley straw (BS), and BC + BS. Soil quality after rice harvesting improved in the BC treated group. The yield components of rice were also improved in the $B C+B S$, compared to other treatments. These effects resulted in increased rice yield and uptake of nutrient contents in the $\mathrm{BC}+\mathrm{BS}$ treatment. Total fluxes of $\mathrm{CH}_{4}$ and $\mathrm{N}_{2} \mathrm{O}$ relative to global warming significantly decreased by $37.3 \%$ and $65.2 \%$ in the BC+BS group than in the IF treatment, respectively. Consequentially, a cropping system with $B C$ and $B S$ is an effective strategy to improve rice productivity and soil quality and also reduce GHG emissions from paddy fields, thereby alleviating global warming.
\end{abstract}

Keywords: Barley straw biochar, Barley straw, Rice season, Global warming, Paddy environment

\section{Introduction}

Recent decades have seen a rise in global warming, a long-term phenomenon resulting in increasing average temperatures of the air and the ocean on the surface of the earth. Future generations are going to see an exacerbation of the temperature. The main reasons for global warming are increasing emissions of $\mathrm{CO}_{2}, \mathrm{CH}_{4}$, and $\mathrm{N}_{2} \mathrm{O}$

\footnotetext{
*Correspondence: dcseo@gnu.ac.kr; chojs@scnu.ac.kr

${ }^{\dagger}$ Se-Won Kang and Jin-Ju Yun have contributed equally to this work

1 Department of Agricultural Life Sciences \& Interdisciplinary

Program in IT-Bio Convergence System, Sunchon National University,

Suncheon 57922, Republic of Korea

${ }^{3}$ Division of Applied Life Science (BK21 Program) \& Institute of Agriculture and Life Science, Gyeongsang National University, Jinju 52828, Republic of Korea

Full list of author information is available at the end of the article
}

due to various human activities. Especially, $\mathrm{CH}_{4}$ and $\mathrm{N}_{2} \mathrm{O}$ are important greenhouse gases; $\mathrm{CH}_{4}$ and $\mathrm{N}_{2} \mathrm{O}$ contribute to 25 times and 298 times the greenhouse effect by $\mathrm{CO}_{2}$, respectively, and $50 \%$ and $60 \%$ of greenhouse gas are generated by agricultural activity $[1,2]$. Hence, these causes require to be controlled.

Rice (Oryza sativa L.) is one of the important cereal resources worldwide. It is differently cultivated under the soil, climatic, and hydrological conditions, and is generally managed under flooded conditions in paddy fields [3]. Sufficient land is required for cultivation since more than $50 \%$ of the global population consumes rice. However, paddy fields are subject to unique problems $[4,5]$. During the rice cultivation period, rice paddies are constantly flooded, and most of the greenhouse gas emitted from rice paddies is $\mathrm{CH}_{4}$ [6]. $\mathrm{CH}_{4}$ generation is affected 
by soil organic matter, $\mathrm{pH}$, temperature, and soil physical properties [7]. It is reported that the causes of $\mathrm{N}_{2} \mathrm{O}$ generation include anaerobic degradation of organic material, kind of crops, and soil characteristics; moreover, fertilizers also contribute greatly towards the emissions [8]. South Korea is one of the countries consuming the maximum inorganic fertilizer per unit area of farmland in the world, thereby generating great amounts of $\mathrm{N}_{2} \mathrm{O}$. Hence, alternate methods that decrease the $\mathrm{CH}_{4}$ and $\mathrm{N}_{2} \mathrm{O}$ emissions during rice cultivation in rice paddies, are the need of the hour [9-11].

Along with global warming, by-products discarded after crop harvest results in environmental pollution [12]. Studies investigating the composting or bio-oil for recycling and utilizing of by-products are therefore being conducted. However, every by-product produced per year is not disposable, and most are either incinerated or neglected.

South Korea produces large quantities of barley straw after barley harvesting. Decomposition of the barley straw in the soil is an important organic resource to improve the fertility of the soil, and efficiently improve the physical condition [13]. Moreover, decomposition of the barley straw is reported to improve crop growth through delivering various nourishments. However, when the barley straws are resolved farm working such as plowing and rice planting work would be inconvenient and if the straws do not decompose enough, rice growth of early-stage would bring inhibition due to organic acids and nitrogen starvation situation in the paddy field [14, 15]. This phenomenon occurs when the incorporation of the barley straw into soil coincides with the time of rice transplanting. Additionally, since burning barley straws results in air contaminants, proper management of barley straw is required for stable rice production in paddy fields $[16,17]$.

Biochar contributes an ideal method that simultaneously recycles agricultural waste, increases crop yield, and reduces GHG emissions from paddy fields. Hence, if barley straws are converted into biochar and subsequently applied to rice paddies, it could help improve the soil physical property and rice growth with reduction of $\mathrm{CH}_{4}$ and $\mathrm{N}_{2} \mathrm{O}$, and would also be an ideal management method $[18,19]$. Moreover, biochar application into the soil can help organic farming by excluding inorganic fertilizers and pesticides, a preferred method for increasing eco-friendly agriculture and reducing the environmental load and concerns of safe farm products.

This study, therefore, focuses on biomass utilization, biomass recycling, crop yield, soil fertility, and greenhouse gas emissions. We also aim to evaluate the effect of combined biochar and barley straw on rice yield, and soil properties, and the $\mathrm{CH}_{4}$ and $\mathrm{N}_{2} \mathrm{O}$ emissions in paddy fields.

\section{Materials and methods}

\section{Raw materials}

The properties of raw soil collected from the topsoil are presented in Table 1 . The raw soil comprises sandy loam soil and has a bulk density of $1.31 \mathrm{Mg} \mathrm{m}^{-3}$, porosity $56.3 \%, \mathrm{pH} 5.87$, and CEC $6.64 \mathrm{cmol}_{\mathrm{c}} \mathrm{kg}^{-1}$.

Barley straw was used to produce biochar as a raw feedstock. The biochar was produced at Sunchon National University in a covered stainless container under oxygen-limited conditions and pyrolyzed in a furnace (DK-1015(E), STI tech, Gumi, Republic of Korea). The container was purged with $\mathrm{N}_{2}$ gas to provide limited oxygen before insertion into the furnace. The furnace controller was programmed to drive the internal biomass chamber to a temperature of $400{ }^{\circ} \mathrm{C}$ at a rate of $3{ }^{\circ} \mathrm{C} \mathrm{min}{ }^{-1}$, after which the peak temperature was sustained for $1 \mathrm{~h}$. The barley straw biochar (BC) was ground and filtered through a $2 \mathrm{~mm}$ sieve for the field experiment. The $\mathrm{pH}$ and nutrient contents of $\mathrm{BC}$ used in the experiment were $\mathrm{pH} 7.72,0.42 \% \mathrm{TN}, 0.30 \% \mathrm{P}_{2} \mathrm{O}_{5}, 1.41 \%$ $\mathrm{K}_{2} \mathrm{O}$, and $21.7 \mathrm{cmol}_{\mathrm{c}} \mathrm{kg}^{-1} \mathrm{CEC}$; the $\mathrm{BC}$ mostly comprised $\mathrm{C}(70 \%>)$. The $\mathrm{OM}, \mathrm{TN}, \mathrm{P}_{2} \mathrm{O}_{5}$, and $\mathrm{K}_{2} \mathrm{O}$ contents of BS were $93.2 \%, 0.27 \%, 0.11 \%$, and $2.34 \%$ respectively (Table 2).

\section{Experimental design}

The field experiment to evaluate growth characteristics of rice, soil properties, and changes of greenhouse gas emission on biochar applications under paddy $\left(34^{\circ} 56^{\prime} 33^{\prime \prime} \mathrm{N}\right.$, $127^{\circ} 33^{\prime} 56^{\prime \prime}$ E) conditions was conducted at Sepung-ri, Gwangyang-eup, Gwangyang-si, Jeollanam-do, South Korea. Figure 1 shows the temperature and precipitation during the experimental period in the above area.

The field experiment was conducted during the rice cultivation season of 2015. Each treatment was separated by a $\mathrm{Cn}, \mathrm{IF}, \mathrm{BC}, \mathrm{BS}$, and $\mathrm{BC}+\mathrm{BS}$ treatment, respectively (Table 3). BC was applied at $2000 \mathrm{~kg} \mathrm{ha}^{-1}$,

Table 1 Soil properties of the experimental site used in this study

\begin{tabular}{|c|c|c|c|c|c|c|c|c|c|c|}
\hline \multirow[t]{2}{*}{ Bulk density $\left(\mathrm{Mg} \mathrm{m}^{-3}\right)$} & \multirow[t]{2}{*}{$\mathrm{pH}\left(1: 5 \mathrm{H}_{2} \mathrm{O}\right)$} & \multirow[t]{2}{*}{$E C\left(d S m^{-1}\right)$} & & & \multirow[t]{2}{*}{ Avail $\mathrm{P}_{2} \mathrm{O}_{5}\left(\mathrm{mg} \mathrm{kg}^{-1}\right)$} & \multicolumn{4}{|c|}{ Exch. cations $\left(\mathrm{cmol}_{\mathrm{c}} \mathrm{kg}^{-1}\right)$} & \multirow[t]{2}{*}{ Soil texture } \\
\hline & & & $\left(\mathrm{g} \mathrm{kg}^{-1}\right)$ & & & $\mathrm{K}$ & $\mathrm{Ca}$ & $\mathrm{Mg}$ & CEC & \\
\hline 1.31 & 5.87 & 0.18 & 16.9 & 1.52 & 64.6 & 0.12 & 4.79 & 0.55 & 6.64 & Sandy loam soil \\
\hline
\end{tabular}


Table 2 Chemical characteristics of biochar and barley straw

\begin{tabular}{|c|c|c|c|c|c|c|}
\hline & $\begin{array}{l}\mathrm{pH} \\
\left(1: 10 \mathrm{H}_{2} \mathrm{O}\right)\end{array}$ & $\begin{array}{l}\text { OM } \\
(\%)\end{array}$ & TN & $\mathrm{P}_{2} \mathrm{O}_{5}$ & $\mathrm{~K}_{2} \mathrm{O}$ & $\begin{array}{l}\text { CEC } \\
\left(\mathrm{cmolc} \mathrm{kg}^{-1}\right)\end{array}$ \\
\hline$B C^{*}$ & 7.72 & - & 0.42 & 0.30 & 1.41 & 21.7 \\
\hline BS & - & 93.2 & 0.27 & 0.11 & 2.34 & - \\
\hline
\end{tabular}

$\mathrm{BC}$ : barley straw biochar; $\mathrm{BS}$ : barley straw

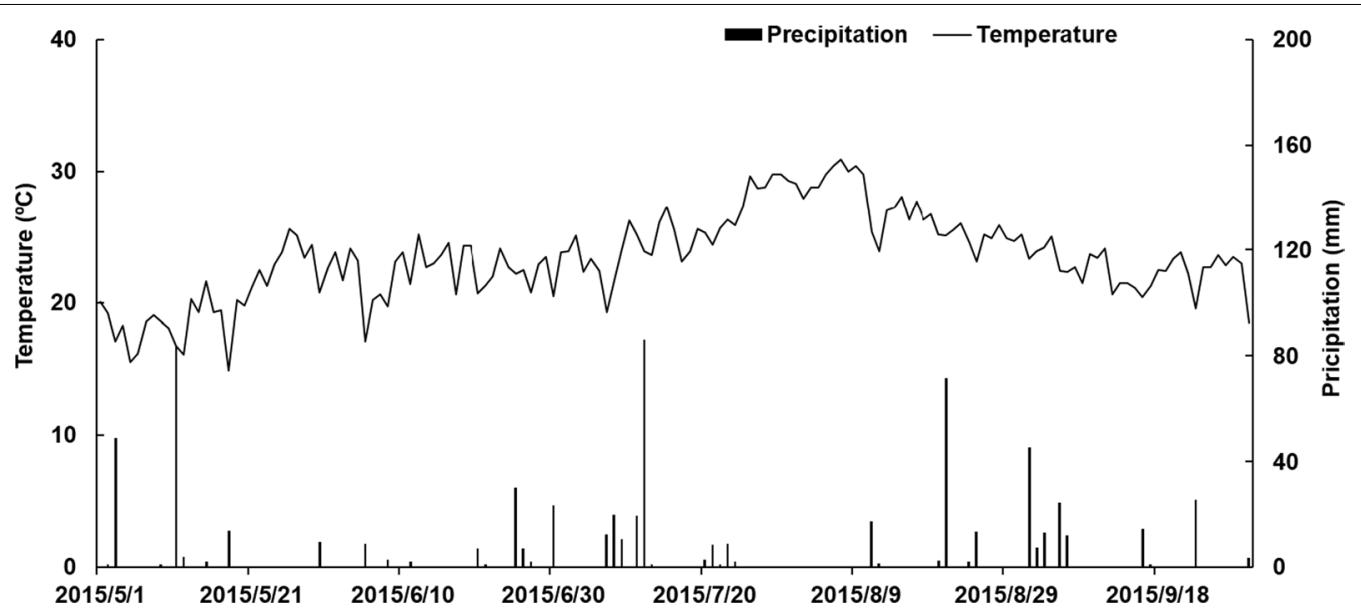

Fig. 1 Mean daily precipitation and air temperature during rice cultivation

Table 3 Treatment conditions used in this experiment

\begin{tabular}{|c|c|c|c|}
\hline Treatments & $\begin{array}{l}\text { Inorganic fertilizer } \\
\left(\mathrm{N}-\mathrm{P}_{2} \mathrm{O}_{5}-\mathrm{K}_{2} \mathrm{O} \mathrm{kg} \mathrm{ha}^{-1}\right)\end{array}$ & $\begin{array}{l}\text { Biochar } \\
\text { (ton ha }^{-1} \text { ) }\end{array}$ & Barley straw \\
\hline $\mathrm{Cn}^{*}$ & - & - & - \\
\hline IF & $90-45-57$ & - & - \\
\hline$B C$ & - & 20 & - \\
\hline BS & - & - & 20 \\
\hline$B C+B S$ & - & 10 & 10 \\
\hline
\end{tabular}

Cn: control; IF: inorganic fertilizer; BC: barley straw biochar; BS: barley straw

whereas IF application was conducted using the Soil Management and Fertilizer Recommendation provided by the Rural Development Administration (RDA), Korea. Inorganic fertilizers were applied $\mathrm{N}-$ $\mathrm{P}_{2} \mathrm{O}_{5}-\mathrm{K}_{2} \mathrm{O}=50-45-40 \mathrm{~kg} \mathrm{ha}^{-1}$ as basal application. First topdressing $\left(20 \mathrm{~kg} \mathrm{~N} \mathrm{ha}^{-1}\right.$ ) was spread about 3 weeks after rice transplanting and second topdressing $\left(20 \mathrm{~kg} \mathrm{~N} \mathrm{ha}^{-1}\right.$ and $\left.17 \mathrm{~kg} \mathrm{~K}_{2} \mathrm{O} \mathrm{ha}^{-1}\right)$ on 8 weeks after rice transplanting. $\mathrm{BC}$ and $\mathrm{BS}$ were evenly spread by a tractor in the field, and incorporated into the soil at a depth of $15 \mathrm{~cm}, 14$ days before rice transplanting. The rice seedlings were transplanted with $20 \mathrm{~cm}$ spacing on 31 May, and rice harvesting was conducted on 30 September.

\section{Sampling and analysis on plant and soil}

To enable sampling of rice plants, one area of each treatment was randomly selected, excluding the edge effects. Rice yield and growth parameters, including culm length, panicle length, number of panicles per hill, number of grains per panicle, 1000 grain, and straws obtained from all treatments were measured at the rice harvesting stage (30 September). The harvested rice plants were then divided into four aliquots: stem, leaf, rice bran, and brown rice. These were dried in a dry oven at $70{ }^{\circ} \mathrm{C}$ for 2 days, after which the characteristics of nutrient uptake (TN, TP, and K) were determined, as described in NIAST [20]. Total nutrient contents were calculated as the sum of $\mathrm{N}, \mathrm{P}_{2} \mathrm{O}_{5}$, and $\mathrm{K}_{2} \mathrm{O}$ contents. Briefly, the collected rice plant samples were digested with $\mathrm{H}_{2} \mathrm{SO}_{4}+\mathrm{HClO}_{4}$, following which the TN and TP analyses were carried out using the Kjeldahl method and UV spectrophotometry, respectively. The $\mathrm{K}$ value was analyzed using an inductively coupled plasma-atomic emission spectrometer (ICP-AEC, Optima 3300EV, Perkin-Elmer, Waltham, MA, USA).

After rice harvesting, soil samples were collected from the surface layer $(15 \mathrm{~cm}$ depth) in each treatment group, air-dried, and passed through a $2 \mathrm{~mm}$ mesh. The chemical properties of the sieved soils were analyzed by different standard methods. The soil $\mathrm{pH}$ and EC were 
measured using a soil-water ratio of 1:5, after shaking the mixture for $30 \mathrm{~min}$. Organic matter (OM) and total nitrogen (TN) analysis were performed using the Tyurin method and Kjeldahl method, respectively. Available phosphorus (Avail. $\mathrm{P}_{2} \mathrm{O}_{5}$ ) was calculated by the Lancaster method, and the exchangeable cations in soil were extracted by $1 \mathrm{~N}-\mathrm{NH}_{4} \mathrm{OAc}$. At the end of the experiment, the bulk density and porosity of soil were measured at different random places in each field, using the core method. In this study, soil analysis was achieved as described in NIAST [20].

\section{Monitoring of $\mathrm{CH}_{4}$ and $\mathrm{N}_{2} \mathrm{O}$}

The $\mathrm{CH}_{4}$ and $\mathrm{N}_{2} \mathrm{O}$ fluxes were monitored through a static chamber. Gas sampling in the paddy field was performed between 1 and 2 p.m. every 7 days. Gases for measuring $\mathrm{CH}_{4}$ and $\mathrm{N}_{2} \mathrm{O}$ were collected at 0,10 , 20 , and $30 \mathrm{~min}$ after chamber closure, using a syringe. The measurements of $\mathrm{CH}_{4}$ and $\mathrm{N}_{2} \mathrm{O}$ were simultaneously analyzed on a gas chromatograph (GC-2014, Shimadzu) with a flame ionization detector (FID) and an electron capture detector (ECD), respectively, as described in the GC manual. The temperature of the equipment for gas analysis was controlled at $55{ }^{\circ} \mathrm{C}$ for a column, $100{ }^{\circ} \mathrm{C}$ for injector, and $230{ }^{\circ} \mathrm{C}$ for detector in FID, and at $50{ }^{\circ} \mathrm{C}$ for column and $310^{\circ} \mathrm{C}$ for detector in ECD. Carrier gases were used with a gas mixture of argon and methane for $\mathrm{CH}_{4}$, and nitrogen gas for $\mathrm{N}_{2} \mathrm{O}$. Fluxes of $\mathrm{CH}_{4}$ and $\mathrm{N}_{2} \mathrm{O}$ were calculated using the following equation [21]:

$$
\mathrm{F}=\rho \times(\mathrm{V} / \mathrm{A}) \times(\Delta \mathrm{c} / \Delta \mathrm{t}) \times(273 / \mathrm{T})
$$

where $\mathrm{F}$ is $\mathrm{CH}_{4}$ and $\mathrm{N}_{2} \mathrm{O}$ flux, $\rho$ is $\mathrm{CH}_{4}$ and $\mathrm{N}_{2} \mathrm{O}$ density, $\mathrm{V}$ is the volume of the chamber $\left(\mathrm{m}^{3}\right)$, $\mathrm{A}$ is the area of the chamber $\left(\mathrm{m}^{2}\right), \Delta \mathrm{c} \times \Delta \mathrm{t}$ is an average increase of gas concentration, and $\mathrm{T}$ is $273+$ mean temperature in the chamber $\left({ }^{\circ} \mathrm{C}\right)$.

The total $\mathrm{CH}_{4}$ and $\mathrm{N}_{2} \mathrm{O}$ fluxes for the entire rice cultivation were computed as described by Singh et al. [22]:

$$
\text { Total } \mathrm{CH}_{4} \text { and } \mathrm{N}_{2} \mathrm{O} \text { flux }=\sum_{i}^{n}(\mathrm{Ri} \times \mathrm{Di})
$$

where $\mathrm{Ri}$ is the rate of $\mathrm{CH}_{4}$ and $\mathrm{N}_{2} \mathrm{O}$ emission in the sampling interval, $\mathrm{Di}$ is the number of days in the sampling interval, and $\mathrm{n}$ is the number of sampling intervals.

The potential for global warming and greenhouse gas intensity were calculated as follows:

$$
\begin{aligned}
& \text { Total Global warming potential }\left(\mathrm{g} \mathrm{CO}_{2} \mathrm{~m}^{-2}\right) \\
& =25 \times \mathrm{TF}-\mathrm{CH}_{4}+298 \times \mathrm{TF}-\mathrm{N}_{2} \mathrm{O}
\end{aligned}
$$

Greenhouse gas intensity $=$ GWP $/ Y$

The effect of $\mathrm{BC}$ on global warming potential (GWP) is described in the IPCC [23] as the total flux (TF) of $\mathrm{CH}_{4}$ and $\mathrm{N}_{2} \mathrm{O}$ over the rice cultivation, and greenhouse gas intensity (GHGI) using GWP and rice yield (Y) is described by Zhang et al. [11].

\section{Statistical analysis}

Statistical analyses of all data were performed using SPSS Version 22. The mean values were measured as an average of three replicates. Each mean value was subjected to analysis of variance (ANOVA) and a comparison of the treatments was performed with Duncan's multiple range test (DMRT) at $5 \%$ probability.

\section{Results}

Growth characteristics and nutrient content of rice plant

The results related to rice growth are presented in Tables 4 and 5. In general, rice growth was best in the $\mathrm{BC}+\mathrm{BS}$ treatment group. The culm length of rice plants was determined to be $54.3,67.0,66.7,61.7$, and $66.5 \mathrm{~cm}$ in $\mathrm{Cn}, \mathrm{IF}, \mathrm{BC}, \mathrm{BS}$, and $\mathrm{BC}+\mathrm{BS}$ treatments, respectively, which showed no difference between

\begin{tabular}{|c|c|c|c|c|c|c|c|}
\hline Treatment & $\begin{array}{l}\text { Culm length } \\
(\mathrm{cm})\end{array}$ & Panicle length & $\begin{array}{l}\text { No. Panicle per } \\
\text { hill }\end{array}$ & $\begin{array}{l}\text { No. grain per } \\
\text { panicle }\end{array}$ & $\begin{array}{l}1000 \text { grain } \\
\text { (g) }\end{array}$ & $\begin{array}{l}\text { Straw } \\
\left(\mathrm{g} \mathrm{m}^{-2}\right)\end{array}$ & Yield \\
\hline $\mathrm{Cn}$ & $54.3 a^{*}$ & $14.3 \mathrm{a}$ & $10.8 \mathrm{a}$ & $89.6 a$ & $21.5 a$ & $423 a$ & $515 a$ \\
\hline IF & $67.0 \mathrm{~b}$ & 15.6ab & 11.4ab & $95.2 \mathrm{ab}$ & $24.8 \mathrm{c}$ & $597 b$ & 559ab \\
\hline$B C$ & $66.7 b$ & 15.7ab & $11.0 \mathrm{a}$ & $94.6 a b$ & $24.3 b c$ & $584 b$ & $542 a$ \\
\hline BS & $61.7 b$ & $14.7 a$ & $10.8 \mathrm{a}$ & $90.2 a$ & 21.9ab & $426 a$ & $526 a$ \\
\hline$B C+B S$ & $66.5 b$ & $16.8 b$ & $12.2 \mathrm{~b}$ & $99.8 b$ & $24.7 c$ & $611 b$ & $593 b$ \\
\hline
\end{tabular}
treatments excluding the $\mathrm{Cn}$ group. The panicle length of the rice plant showed similar measurements as the

Table 4 Growth characteristics of rice by biochar application

*Means by the same within a column are not significantly different at 0.05 probability level according to Duncan's Multiple Range Test 
Table 5 Nutrient contents of harvested rice plant

\begin{tabular}{|c|c|c|c|c|c|}
\hline & & Stem & Leaf & Rice bran & Brown rice \\
\hline \multirow[t]{5}{*}{ TN (\%) } & $\mathrm{Cn}$ & $0.44 a^{*}$ & $0.95 a$ & $0.38 a$ & $0.60 a$ \\
\hline & IF & $0.47 b c$ & $0.99 b$ & $0.48 d$ & $0.71 \mathrm{c}$ \\
\hline & $B C$ & $0.45 a b$ & $0.97 a b$ & $0.46 c$ & $0.64 b$ \\
\hline & BS & $0.44 a$ & $0.95 a$ & $0.41 b$ & $0.62 a b$ \\
\hline & $B C+B S$ & $0.49 c$ & $1.18 \mathrm{c}$ & $0.49 d$ & $0.76 \mathrm{~d}$ \\
\hline \multirow[t]{5}{*}{ TP (\%) } & $\mathrm{Cn}$ & $0.02 \mathrm{a}$ & $0.04 a$ & $0.08 a$ & $0.26 a$ \\
\hline & IF & $0.04 c$ & $0.05 b$ & $0.11 \mathrm{c}$ & $0.30 c$ \\
\hline & $B C$ & $0.03 b$ & $0.05 a$ & $0.09 b$ & $0.28 b$ \\
\hline & BS & $0.02 \mathrm{a}$ & $0.05 a$ & $0.08 a$ & $0.27 a b$ \\
\hline & $B C+B S$ & $0.05 c$ & $0.05 b$ & $0.10 c$ & $0.36 \mathrm{~d}$ \\
\hline \multirow[t]{5}{*}{ K (\%) } & $\mathrm{Cn}$ & $1.12 b$ & $0.62 a$ & $0.69 a$ & $0.14 a$ \\
\hline & $\mathrm{IF}$ & $0.98 a$ & $0.69 b$ & $0.78 b c$ & $0.16 b$ \\
\hline & $B C$ & $0.98 a$ & $0.72 b$ & $0.74 a b$ & $0.17 b$ \\
\hline & BS & $0.96 a$ & $0.63 a$ & $0.75 b$ & $0.13 a$ \\
\hline & $B C+B S$ & $1.06 \mathrm{~b}$ & $0.72 b$ & $0.83 c$ & $0.16 b$ \\
\hline
\end{tabular}

*Means by the same within a column are not significantly different at 0.05 probability level according to Duncan's Multiple Range Test

culm length. The number of panicles per hill and number of grains per panicle for all treatments ranged from $10.8 \sim 12.2$ and $89.6 \sim 99.8$ ea respectively, and were significantly not different. The straw and yield of rice plants were generally higher in the order of BC+BS, IF, $\mathrm{BC}, \mathrm{BS}$, and $\mathrm{Cn}$ treatments.

The TN, TP, and $\mathrm{K}$ contents of the rice plant in the different sections are presented in Table 5 . The TN content measured was in the order of leaf $>$ brown rice $>$ stem $\geqq$ rice bran. The TP content was highest in brown rice, and the $\mathrm{K}$ content in all treatments ranged from $0.96 \sim 1.12 \%$ for stem, $0.62 \sim 0.72 \%$ for leaf, $0.69 \sim 0.83 \%$ for rice bran, and $0.13 \sim 0.17 \%$ for brown rice.

\section{Soil physicochemical properties}

The physicochemical properties of soil after rice harvesting are presented in Fig. 2. BC application generally and significantly improved the conditions of raw soil, as compared to soil BC treatment. The bulk density and porosity of soil after rice harvesting were affected by BC and BS application. The bulk density of soil markedly decreased by $0.08 \sim 0.09 \mathrm{Mg} \mathrm{m}^{-3}$ in the BC treatments groups, as compared to $\mathrm{Cn}$ and IF treatments. The porosity of the soil in $\mathrm{BC}, \mathrm{BS}$, and $\mathrm{BC}+\mathrm{BS}$ treatments was higher (range, $2.38 \sim 3.31 \%$ ) than determined in other treatments. Ranges of soil chemical properties after rice harvesting are as follows: $\mathrm{pH} 5.89$ to 6.20 , EC 0.18 to $0.25 \mathrm{dS} \mathrm{m}^{-1}$, OM content 15.8 to $18.7 \mathrm{~g} \mathrm{~kg}^{-1}$, TN content 1.44 to $1.72 \mathrm{~g} \mathrm{~kg}^{-1}$, Avail. $\mathrm{P}_{2} \mathrm{O}_{5}$ content 57.2 to $61.7 \mathrm{mg} \mathrm{kg}^{-1}$, CEC 6.71 to $7.43 \mathrm{cmol}_{\mathrm{c}} \mathrm{kg}^{-1}$.

\section{Changes in $\mathrm{CH}_{4}$ and $\mathrm{N}_{2} \mathrm{O}$ emission rates}

The change in $\mathrm{CH}_{4}$ emission rate varied significantly by $\mathrm{BC}$ application and sampling dates (Fig. 3). The $\mathrm{CH}_{4}$ emission rates with and without $\mathrm{BC}$ treatments respectively ranged from $6.16 \sim 6.20$ and $11.4 \sim 12.2 \mathrm{mg} \mathrm{m}^{-2} \mathrm{~h}^{-1}$ at 7 days, $9.34 \sim 12.5$ and $15.5 \sim 16.5 \mathrm{mg} \mathrm{m}^{-2} \mathrm{~h}^{-1}$ at 14 days, and $27.6 \sim 28.0$ and $41.4 \sim 44.7 \mathrm{mg} \mathrm{m}^{-2} \mathrm{~h}^{-1}$ at 21 days after transplanting. Thereafter, $\mathrm{CH}_{4}$ emission rates in $\mathrm{Cn}, \mathrm{IF}, \mathrm{BC}, \mathrm{BS}$, and $\mathrm{BC}+\mathrm{BS}$ treatments were maintained in the range of $6.34 \sim 19.7,5.32 \sim 23.9$, $1.32 \sim 14.8,4.54 \sim 20.5$, and $1.45 \sim 13.4 \mathrm{mg} \mathrm{m}^{-2} \mathrm{~h}^{-1}$, respectively, until 126 days after transplanting. In particular, a minimum $\mathrm{CH}_{4}$ emission rate was observed at the rice harvesting stage for all treatments, due to temporary aerobic conditions. Thus, the pattern of $\mathrm{CH}_{4}$ emission rate for all treatments increased rapidly until 21 days after transplanting, and thereafter gradually decreases until the rice harvesting stage.

Changes in the rate of $\mathrm{N}_{2} \mathrm{O}$ emission also varied significantly by amounts of inorganic fertilizer added and sampling dates (Fig. 3). The $\mathrm{N}_{2} \mathrm{O}$ emission rate ranged between 6.03 174 ug m $\mathrm{ug} \mathrm{h}^{-1}$ (average $54.6 \mathrm{ug} \mathrm{m}^{-2} \mathrm{~h}^{-1}$ ) for $\mathrm{Cn}, 94.7 \sim 653 \mathrm{ug} \mathrm{m}^{-2} \mathrm{~h}^{-1}$ (average $304 \mathrm{ug} \mathrm{m}^{-2} \mathrm{~h}^{-1}$ ) for IF, 13.8 353 ug m $\mathrm{ug}^{-2} \mathrm{~h}^{-1}$ (average $81.5 \mathrm{ug} \mathrm{m}^{-2} \mathrm{~h}^{-1}$ ) for BC, $39.1 \sim 322 \mathrm{ug} \mathrm{m}^{-2} \mathrm{~h}^{-1}$ (average $123 \mathrm{ug} \mathrm{m}^{-2} \mathrm{~h}^{-1}$ ) for BS, and 36.5 247 ug m $\mathrm{m}^{-2} \mathrm{~h}^{-1}$ (average $106 \mathrm{ug}$ $\mathrm{m}^{-2} \mathrm{~h}^{-1}$ ) for $\mathrm{BC}+\mathrm{BS}$ treatment during rice cultivation. Generally, the peak of $\mathrm{N}_{2} \mathrm{O}$ production was significantly affected by inorganic fertilizer application. Thus, the pattern of $\mathrm{N}_{2} \mathrm{O}$ emission rate varied as per the widely different treatments applied.

\section{Discussion}

Biochar or organic material application to crop fields is recommended for improving plant growth and multifaceted functions of the soil [24-28]. Our study, our findings indicate that combined $\mathrm{BC}+\mathrm{BS}$ application promotes rice yield, improves soil fertility, and decreases fluxes of $\mathrm{CH}_{4}$ and $\mathrm{N}_{2} \mathrm{O}$.

Biochar is a highly heterogeneous material [29], and its application to soil is known to alter the physical [30], chemical [31], and biological [32] properties of soil. Moreover, biochar application contributes to the increased availability of nutrients for crop growth [33], and is a direct source of nutrients for plant uptake [34]. These studies have indicated a positive effect of biochar application for increasing crop yield in agricultural fields. For example, Gwenzi et al. [35] reported that biochar application improves maize growth, and Liu et al. [36] reported that rapeseed and sweet potato yields are increased after biochar treatments $\left(40 \mathrm{t} \mathrm{ha}^{-1}\right)(36.0 \%$ and $53.8 \%$, respectively) as compared to their controls. 

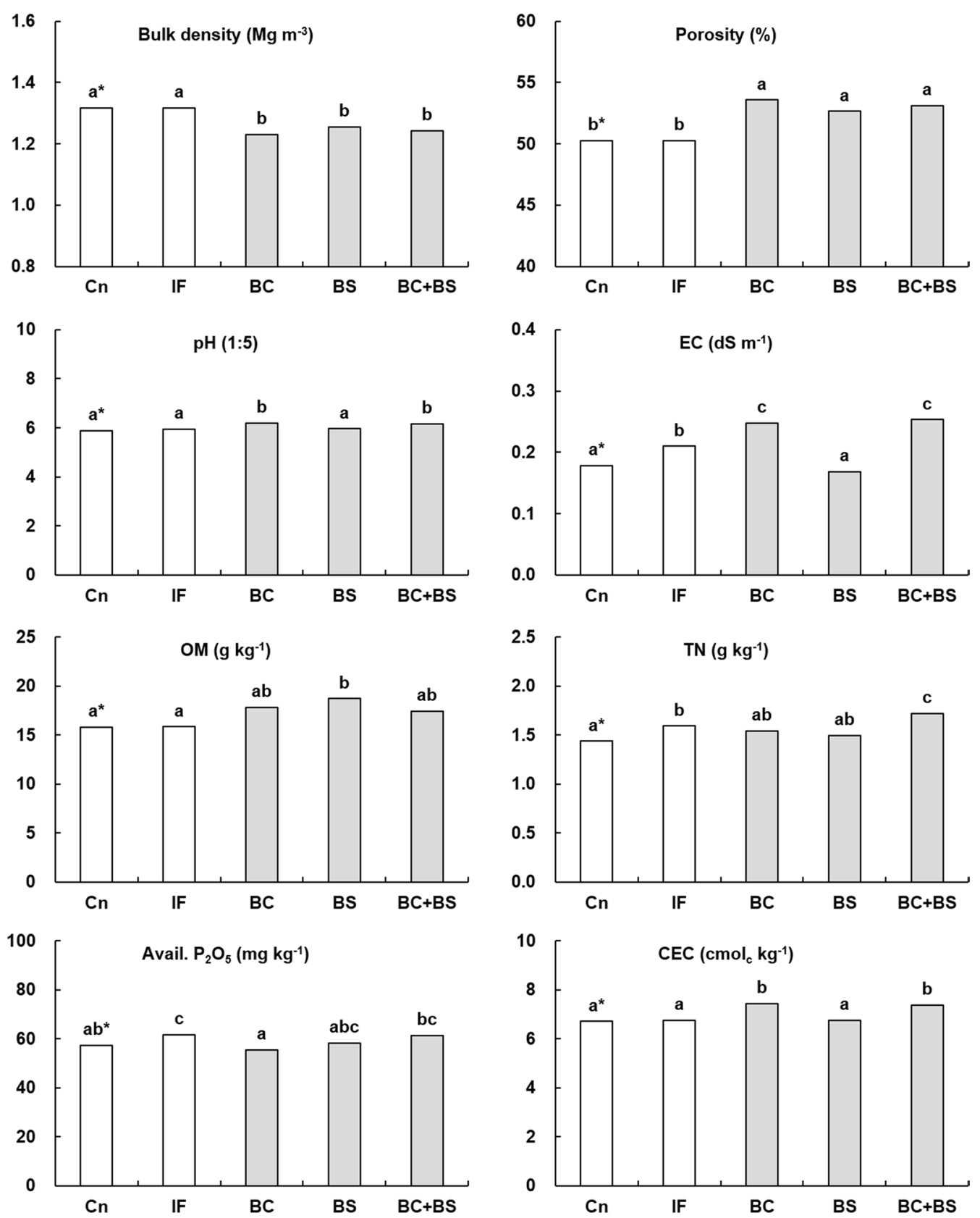

Fig. 2 Changes in soil chemical characteristics after rice harvesting for each tested treatment group (*Means by the same within a column are not significantly different at 0.05 probability level according to Duncan's Multiple Range Test)

Furthermore, several researchers have determined multiple applications of biochar and nutrients (use as fertilizer, and organic matter to improve crop growth) due to the high nutrient retention capacity of biochar [28, 37-39]. In the present study, the combined $\mathrm{BC}$ and $\mathrm{BS}$ exert the maximum effect on the rice yield and yield components in the paddy field. In particular, rice yields are significantly increased by the $\mathrm{BC}+\mathrm{BS}$ treatment (increments of $8.5 \%$ for IF, $3.3 \%$ for BC, $2.0 \%$ for BS, and $15.1 \%$ for $\mathrm{BC}+\mathrm{BS}$ ), relative to the $\mathrm{Cn}$ treatment (Table 3). This is in agreement with previous studies: Liu et al. [40] reported $8.5 \sim 10.7 \%$ increased rice yield in rice straw biochar application; Zhang et al. [11] showed that rice yield in biochar treatments of $10 \mathrm{t}, 20 \mathrm{t}$, and $40 \mathrm{t} \mathrm{ha}^{-1}$ increased in the range 9.2-27.6\% during two cycles; Zhang et al. [41] also reported that biochar treatments $(10 \mathrm{t}$ and $40 \mathrm{t}$ 

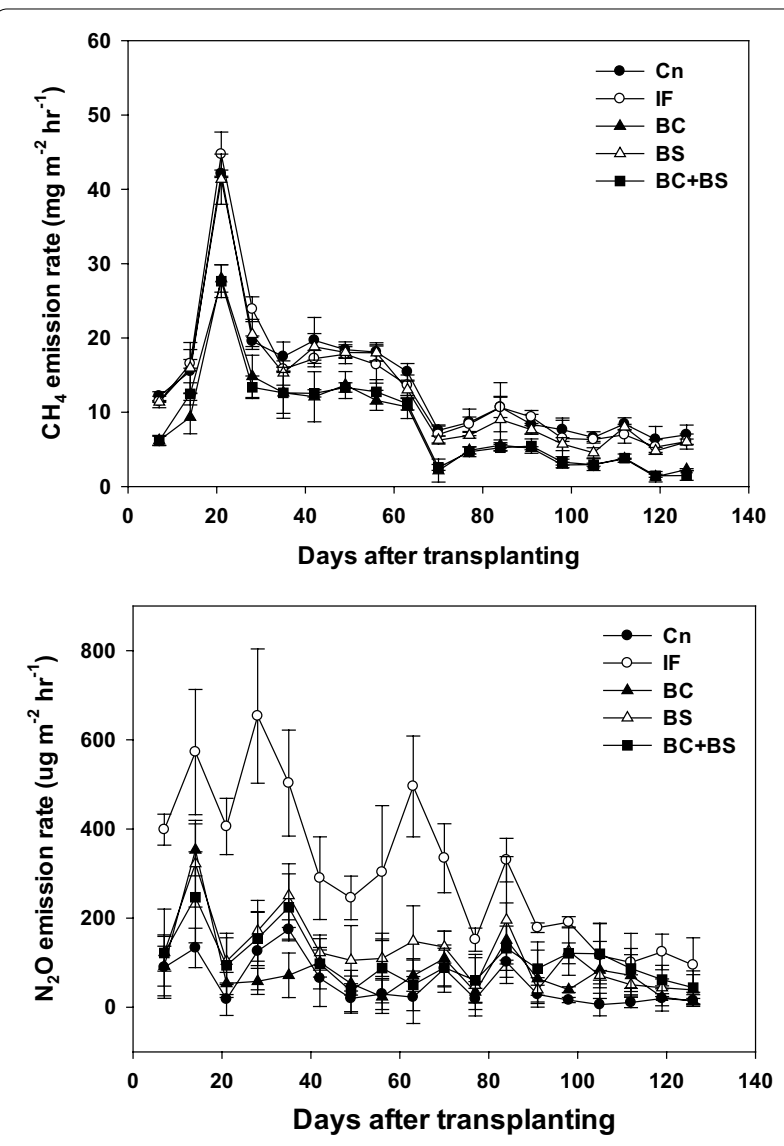

Fig. 3 Changes in $\mathrm{CH}_{4}$ and $\mathrm{N}_{2} \mathrm{O}$ emission rate during rice cultivation

$\mathrm{ha}^{-1}$ ), regardless of $\mathrm{N}$ fertilization, improve the rice yield by $9-14 \%$, compared to their control treatment. Moreover, Zhang et al. [42] and Thammasom et al. [43] reported that straw incorporation in rice paddy is effective in increasing rice yield due to improve soil fertility through decomposition of organic matter. The results from the current study observed higher inorganic element contents of rice plants in $\mathrm{BC}+\mathrm{BS}$ treatment through the improvement of soil $\mathrm{pH}$ and $\mathrm{CEC}$ after biochar application, and supply of nutrients by adding straw (Fig. 4).

The important physical properties of soil include compaction, aggregation, pore, air, and water content $[15,44$, 45]. Bulk density and porosity are important indicators of the physical status of the soil. In this study, the results obtained in field experiments indicate that BC and BS application significantly affect the soil's physical properties. Biochar or organic materials such as straw, green manure, and compost are known to effectually improve the soil as well as crop productivity [46-48]. This could be attributed to the low density of $\mathrm{BC}$ and $\mathrm{BS}$ relative to the soil, thereby resulting in a direct dilution effect [49]. The soil diluted by BC or BS may change the internal structure and surface area of soil due to increased soil porosity, thus improving the flow of water and air, and also the aggregate stability [50, 51]. Tan et al. [45] reported that bulk density of soil treated with $200 \mathrm{~g} \mathrm{~kg}^{-1}$ biochar decreased by $20.45 \%$ as compared to control treatment. Blanco-Canqui [52] reported the results of another researcher that biochar application reduces the bulk density by $12 \%$ on an average, regardless of soil condition and biochar rate. Moreover, Thammasom et al. [43] reported that biochar and straw application significantly decrease bulk density in paddy soil. Similar to the previous reports, our study also showed that the application of BC and BS lowers the bulk density of soil and soil porosity.

Soil chemical properties in paddy fields were generally improved by $\mathrm{BC}$ and $\mathrm{BS}$ application, with significantly greater changes observed after $\mathrm{BC}$ treatments as compared to BS treatment. BC application showed significant

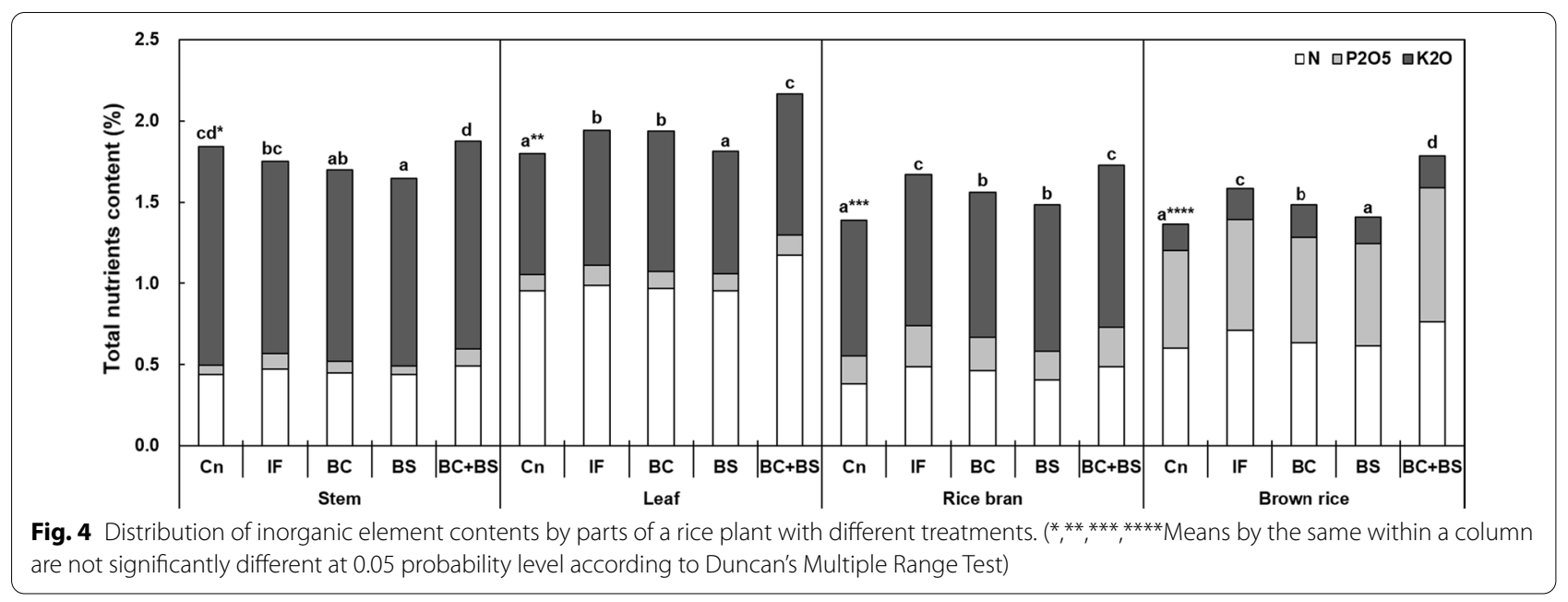


increases in $\mathrm{pH}$ and CEC as compared to the $\mathrm{Cn}$ and IF treatments. In particular, improvement of soil chemical factors was more effective with $\mathrm{BC}+\mathrm{BS}$ treatment than other treatments. This phenomenon may be attributable to the higher $\mathrm{pH}$ and $\mathrm{CEC}$ of $\mathrm{BC}$ than soil, and nutrients supplied by $\mathrm{BS}$. These findings are in agreement with the reports of Tan et al. [45], which reveal that soil $\mathrm{pH}$ by biochar application increases by $0.61-0.85$ units as compared to control soil under different soil types. Liu et al. [40] also reported over 2 seasons that the $\mathrm{pH}$ of applied $\mathrm{BC}$ soil in a paddy field increases by $0.07-0.18$ units compared with their control soil. Butterly et al. [53] observed an increase in soil $\mathrm{pH}$ due to the incorporation of higher alkalinity material. Thammasom et al. [43] reported that CEC of soil using biochar and straw application significantly increases than control soil because of mineralization of inorganic elements through decomposition of biochar and straw. It has also been reported that the $\mathrm{pH}$ and CEC in soil are closely related [54-57]. Considering the above, we determined that rice yield in $\mathrm{BC}+\mathrm{BS}$ treatment is higher than other treatments due to improved nutrient availability by increasing soil fertility.

In paddy fields, GHG emission is affected by various environmental factors such as microbial activity, aeration, temperature, fertilizer, and resource of nutrient supply [7, 58-60]. Our study assessed the positive effect of biochar application with barley straw on $\mathrm{CH}_{4}$, $\mathrm{N}_{2} \mathrm{O}$, GWP, and GHGI (Table 5). The total $\mathrm{CH}_{4}$ fluxes from the rice cultivation field were 42.0, 41.0, 25.2, 38.8, and $25.7 \mathrm{~g} \mathrm{~m}^{-2}$ after treatment with $\mathrm{Cn}, \mathrm{IF}, \mathrm{BC}, \mathrm{BS}$, and $\mathrm{BC}+\mathrm{BS}$, respectively. These results indicate that treatments with $\mathrm{BC}$ application lowers the $\mathrm{CH}_{4}$ emission more than treatment without $\mathrm{BC}$. We further determined that the reduction efficiency of $\mathrm{CH}_{4}$ fluxes by $\mathrm{BC}$ application was $33.8-40.0 \%$ more than soils treated with $\mathrm{Cn}$, IF, and BS. The total $\mathrm{N}_{2} \mathrm{O}$ fluxes were higher in the order IF $\left(0.92 \mathrm{~g} \mathrm{~m}^{-2}\right)>\mathrm{BS}\left(0.37 \mathrm{~g} \mathrm{~m}^{-2}\right) \geqq \mathrm{BC}+\mathrm{BS}$ $\left(0.32 \mathrm{~g} \mathrm{~m}^{-2}\right)>\mathrm{BC}\left(0.25 \mathrm{~g} \mathrm{~m}^{-2}\right)>\mathrm{Cn}\left(0.16 \mathrm{~g} \mathrm{~m}^{-2}\right)$. We found significantly decreased fluxes of $\mathrm{CH}_{4}$ and $\mathrm{N}_{2} \mathrm{O}$ under different applications of BC. Several studies have previously reported the advantage of biochar application on emissions of $\mathrm{CH}_{4}$ and $\mathrm{N}_{2} \mathrm{O}$ during crop cultivation $[10,56,57,61-66]$.

As shown in Table 6, GWP was calculated using total $\mathrm{CH}_{4}$ and $\mathrm{N}_{2} \mathrm{O}$ fluxes obtained from results during rice cultivation. In declining order, GWP in tested soils were IF $\left(13.0\right.$ ton $\left.\mathrm{CO}_{2} \mathrm{ha}^{-1}\right)>\mathrm{Cn}>\mathrm{BS}>\mathrm{BC}+\mathrm{BS}>\mathrm{BC}$ treatments. $\mathrm{BC}$ application decreases both, mean $\mathrm{CH}_{4}$ and $\mathrm{N}_{2} \mathrm{O}$, emissions in the rice field. The $\mathrm{BC}$ and $\mathrm{BC}+\mathrm{BS}$ treatments decrease the GWP by $32.9-36.1 \%$, $43.2-45.9 \%$, and $31.7-34.9 \%$ when compared to $\mathrm{Cn}$, IF, and BS, respectively. Benefits of biochar application include restriction of methanogen activity [9],
Table 6 Total fluxes of $\mathrm{CH}_{4}$ and $\mathrm{N}_{2} \mathrm{O}$, GWP, and GHGl during rice cultivation

\begin{tabular}{|c|c|c|c|c|}
\hline \multirow[t]{2}{*}{ Treatments } & \multicolumn{2}{|c|}{ Total fluxes $\left(\mathrm{g} \mathrm{m}^{-2}\right)$} & \multirow{2}{*}{$\begin{array}{l}\text { GWP (ton } \mathrm{CO}_{2} \\
\text { eq. } \mathrm{ha}^{-1} \text { ) }\end{array}$} & \multirow[t]{2}{*}{ GHGI } \\
\hline & $\mathrm{CH}_{4}$ & $\mathrm{~N}_{2} \mathrm{O}$ & & \\
\hline $\mathrm{Cn}$ & $42.0 c^{*}$ & $0.16 a$ & $11.0 \mathrm{~b}$ & 2.13 \\
\hline $\mathbb{I F}$ & $41.0 \mathrm{bc}$ & $0.92 d$ & $13.0 \mathrm{c}$ & 2.32 \\
\hline$B C$ & $25.2 \mathrm{a}$ & $0.25 b$ & $7.03 a$ & 1.32 \\
\hline BS & $38.8 \mathrm{~b}$ & $0.37 c$ & $10.8 b$ & 2.26 \\
\hline$B C+B S$ & $25.7 a$ & $0.32 c$ & $7.38 a$ & 1.24 \\
\hline
\end{tabular}

*Means by the same within a column are not significantly different at 0.05 probability level according to Duncan's Multiple Range Test

increasing $\mathrm{CH}_{4}$ oxidation, soil $\mathrm{pH}$ and aeration [60, 67], increased denitrification rate [64], enhancement of the last step from $\mathrm{N}_{2} \mathrm{O}$ to $\mathrm{N}_{2}$, the activity of $\mathrm{N}_{2} \mathrm{O}$ sorption surface [68], and inhibition of $\mathrm{N}_{2} \mathrm{O}$ production [69]. These mechanisms are commonly involved in improving soil physical properties after biochar application. Our results also revealed that GHGI $(\mathrm{GWP} / \mathrm{Y})$ is dependent on the application of $\mathrm{BC}$ and $\mathrm{BS}$; we determined the highest rice yield and decreased $\mathrm{CH}_{4}$ and $\mathrm{N}_{2} \mathrm{O}$ emission in $\mathrm{BC}+\mathrm{BS}$ treatment during the rice cultivation period.

In our experiment, the combined treatment of $\mathrm{BC}$ and $\mathrm{BS}$ is more effective than the individual application of IF, BC, and BS treatments on rice yield and GHGs emission. Taken together, our results suggest that BC application with BS is a potentially useful cropping system for environmental-friendly agriculture and global warming mitigation in the rice paddy.

\section{Acknowledgements}

This work was supported by Korea Institute of Planning and Evaluation for Technology in Food, Agriculture and Forestry (IPET) through Technology Commercialization Support Program, funded by Ministry of Agriculture, Food and Rural Affairs (MAFRA)(821007-03). This work was supported by a grant from the Ministry of Science and ICT (MSIT) through the National Research Foundation (NRF) of Korea (NRF-2019R1A4A1029125). Moreover, this work was supported by the National Research Foundation of Korea (NRF) grant funded by the Korea government (MSIT) (NRF-2020R1/1A1A01058224). And this work was carried out with the support of "Cooperative Research Program for Agriculture Science and Technology Development (Project No. PJ015568)" Rural Development Administration, Republic of Korea.

\section{Authors' contributions}

SWK, JJY, DCS, and JSC designed and conducted the experiment as well as wrote the manuscript. JHP conducted plant and soil analysis, $\mathrm{CH}_{4}$ and $\mathrm{N}_{2} \mathrm{O}$ measurement and interpretation. YHC, and JHP inspired the overall work and revised the final manuscript. All authors read and approved the final manuscript.

\section{Funding}

Not applicable.

Availability of data and materials

All data is available in the main text. 


\section{Declarations}

\section{Competing interests}

The authors declare that they have no competing interests.

\section{Author details}

'Department of Agricultural Life Sciences \& Interdisciplinary Program in IT-Bio Convergence System, Sunchon National University, Suncheon 57922, Republic of Korea. ${ }^{2}$ Department of Life Resources Industry, Dong-A University, Busan 49315, Republic of Korea. ${ }^{3}$ Division of Applied Life Science (BK21 Program) \& Institute of Agriculture and Life Science, Gyeongsang National University, Jinju 52828, Republic of Korea. ${ }^{4}$ Department of Applied Life Science (Institute of Agriculture and Life Science), Gyeongsang National University, Jinju 52828, Republic of Korea.

Received: 5 November 2021 Accepted: 11 December 2021

Published online: 23 December 2021

\section{References}

1. Linquist B, van Groenigen KJ, Adviento-Borbe MA, Pittelkow C, van Kessel C (2012) An agronomic assessment of greenhouse gas emissions from major cereal crops. Glob Change Biol 18:194-209

2. Wang W, Neogi S, Lai DYF, Zeng C, Wang C, Zeng D (2017) Effects of industrial and agricultural waste amendment on soil greenhouse gas production in a paddy field in Southeastern China. Atmos Environ 164:239-249

3. Chaudhary VP, Singh KK, Pratibha G, Ranjan B, Shamim M, Srinivas I, Anurag $P$ (2017) Energy conservation and greenhouse gas mitigation under different production systems in rice cultivation. Energy 130:307-317

4. FAO (Food and Agricultural Organization of the United Nations) (2009) OECD-FAO Agricultural Outlook 2011-2030

5. Wang W, Lai DYF, Wang C, Tong C, Zeng C (2016) Effects of inorganic amendments, rice cultivars and cultivation methods on greenhouse gas emissions and rice productivity in a subtropical paddy field. Ecol Eng 95:770-778

6. Cicerone RJ, Shettler JD (1981) Sources of atmospheric methane: measurements in rice paddies and discussion. J Geophys Res 86:7203-7209

7. Mosier AR, Delgado JA, Keller M (1998) Methane and nitrous oxide fluxes in an acid oxisol in western Puerto Rico: effects of tillage, liming, and fertilization. Soil Biol Biochem 30:2087-2098

8. Crutzen PJ, Mosier AR, Smith KA, Winiwarter W (2008) $\mathrm{N}_{2} \mathrm{O}$ release from agro-biofuel production negates global warming reduction by replacing fossil fuels. Atmos Chem Phys 8:389-395

9. Feng $Y, X u Y, Y u Y, X i e Z$, Lin X (2012) Mechanisms of biochar decreasing methane emission from paddy soils. Soil Biol Biochem 46:80-88

10. Liu $Y$, Yang $M$, Wu Y, Wang $\mathrm{H}$, Chen $\mathrm{Y}$, Wu W (2011) Reducing $\mathrm{CH}_{4}$ and $\mathrm{CO}_{2}$ emissions from water logged paddy soil with biochar. J Soil Sediments 11:930-939

11. Zhang A, Bian R, Pan G, Cui L, Hussain Q, Li L, Zheng J, Zheng J, Zhang X, Han X, Yu X (2012) Effects of biochar amendment on soil quality, crop yield and greenhouse gas emission in a rice paddy: a field study of 2 consecutive rice growing cycles. Field Crop Res 127:153-160

12. Külcü R, Yaldiz O (2014) The composting of agricultural wastes and the new parameter for the assessment of the process. Ecol Eng 69:220-225

13. Shin SO, Hwang CD, Kim SY, Park ST (2006) Influence of long-term barley straw addition on soil nitrogen dynamics and growth and yield of rice in dry direct seeding under rice-barely double cropping. Korean J Crop Sci 18:112-115

14. Gotoh S, Onikura Y (1971) Organic acids in flooded soil receiving added rice straw and their effect on the growth of rice. Soil Sci Plant Nutr 17:1-8

15. Kang SW (2016) Utilization plan of barley straw biochar for crop rotations of barley-rice. Doctoral Thesis. Sunchon National University, Korea

16. Ko JY, Kang HW, Park KB (1996) Effects of water management rice straw and compost on methane emission in dry seeded rice. Korean J Soil Sci Fert 29:212-217

17. Yagi K, Minami K (1990) Effect of organic matter application on methane emission from some Japanese paddy fields. Soil Sci Plant Nutr 36:599-610
18. Angst TE, Six J, Reay DS, Sohi SP (2014) Impact of pine chip biochar on trace greenhouse gas emissions and soil nutrient dynamics in an annual ryegrass system in California. Agr Ecosyst Environ 191:17-26

19. Case SDC, McNamara NP, Reay DS, Whitaker J (2012) The effect of biochar addition on $\mathrm{N}_{2} \mathrm{O}$ and $\mathrm{CO}_{2}$ emissions from a sandy loam soil-the role of soil aeration. Soil Biol Biochem 51:125-134

20. NIAST (2000) Methods of soil and plant analysis, National Institute of Agricultural Science and Technology, RDA, Suwon, Korea

21. Rolston DE (1986) Gas flux. In A. Klute (ed), Method of soil analysis. Part 1. 2nd ed. Agron. Monogr. 9. ASA and SSSA, Madison, WI, pp 1103-1119

22. Singh S, Singh JS, Kashyap AK (1999) Methane flux from irrigated rice fields in relation to crop growth and $\mathrm{N}$-fertilization. Soil Biol Biochem $31: 1219-1228$

23. IPCC (2007) Changes in atmospheric constituents and in radiative forcing. In Climate Change 2007: The Physical Science Basis. Contribution of Working Group I to the Fourth Assessment Report of the Intergovernmental Panel on Climate Change. Solomon S, Qin D, Manning M, et al., Eds. Cambridge University Press, Cambridge, UK

24. Carvalho MTM, Madari BE, Bastiaans L, van Oort PAJ, Leal WGO, Heinemann AB, da Silva MAS, Maia AHN, Parsons D, Meinke H (2016) Properties of a clay soil from 1.5 to 3.5 years after biochar application and the impact on rice yield. Geoderma 276:7-18

25. He L, Zhao X, Wang S, Xing G (2016) The effects of rice-straw biochar addition on nitrification activity and nitrous oxide emissions in two Oxisols. Soil Tillage Res 164:52-62

26. Khadem A, Raiesi F (2017) Responses of microbial performance and community to corn biochar in calcareous sandy and clayey soils. Appl Soil Ecol 114:16-27

27. Sui Y, Gao J, Liu C, Zhang W, Lan Y, Li S, Meng J, Xu Z, Tang L (2016) Interactive effects of straw-derived biochar and $\mathrm{N}$ fertilization on soil $\mathrm{C}$ storage and rice productivity in rice paddies of Northeast China. Sci Total Environ 544:203-210

28. Kim J, Yoo G, Kim D, Ding W, Kang H (2017) Combined application of biochar and slow-release fertilizer reduces methane emission but enhances rice yield by different mechanisms. Appl Soil Ecol 117-118:57-62

29. Kloss S, Zehetner F, Dellantonio A, Hamid R, Ottner F, Liedtke V, Schwanninger M, Gerzabek MH, Soja G (2012) Characterization of slow pyrolysis biochars: effects of feedstocks and pyrolysis temperature on biochar properties. J Environ Qual 41:990-1000

30. Rogovska N, Laird DA, Karlen DL (2016) Corn and soil response to biochar application and stover harvest. Field Crop Res 187:96-106

31. Kloss S, Zehetner F, Oburger E, Buecker J, Kitzler B, Wenzel WW, Wimmer B, Soja G (2014) Trace element concentrations in leachates and mustard plant tissue (Sinapis alba L.) after biochar application to temperate soils. Sci Total Environ 481:498-508

32. Bera T, Collins HP, Alva AK, Purakayastha TJ, Patra AK (2016) Biochar and manure effluent effects on soil biochemical properties under corn production. Appl Soil Biol 107:360-367

33. Chan KY, Zwieten LV, Meszaros I, Downie A, Joseph S (2007) Agronomic values of green waste biochar as a soil amendment. Aust J Soil Res 45:629-634

34. Jeffery S, Verheijen F, Van Der Velde M, Bastos A (2011) A quantitative review of the effects of biochar application to soils on crop productivity using meta-analysis. Agr Ecosyst Environ 144:175-187

35. Gwenzi W, Muzava M, Mapanda F, Tauro TP (2016) Comparative shortterm effects of sewage sludge and its biochar on soil properties, maize growth and uptake of nutrients on a tropical clay soil in Zimbabwe. J Integr Agric 15:1395-1406

36. Liu Z, Chen X, Jing Y, Li Q, Zhang J, Huang Q (2014) Effects of biochar amendment on rapeseed and sweet potato yields and water stable aggregate in upland red soil. CATENA 123:45-51

37. Yamato M, Okimori Y, Wibowo IF, Anshori S, Ogawa M (2006) Effects of the application of charred bark of Acacia mangium on the yield of maize, cowpea and peanut, and soil chemical properties on South Sumatra, Indonesia. Soil Sci Plant Nutr 52:489-496

38. Fahad S, Hussain S, Saud S, Hassan S, Tanveer M, Ihsan MZ, Shah AN, Ullah A, Nasrullah KF, Ullah S, Alharby H, Nasim W, Wu C, Huang J (2016) A combined application of biochar and phosphorus alleviates heat-induced adversities on physiological, agronomical and quality attributes of rice. Plant Physiol Biochem 103:191-198 
39. Zhou Y, Berruti F, Greenhalf C, Henry HAL (2017) Combined effects of biochar amendment, leguminous cover crop addition and snow removal on nitrogen leaching losses and nitrogen retention over winter and subsequent yield of a test crop (Eruca sativa L.). Soil Biol Biochem 114:220-228

40. Liu Y, Lu H, Yang S, Wang Y (2016) Impacts of biochar addition on rice yield and soil properties in a cold waterlogged paddy for two crop seasons. Field Crop Res 191:161-167

41. Zhang A, Cui L, Pan G, Li L, Hussain Q, Zhang X, Zheng J, Crowley D (2010) Effect of biochar amendment on yield and methane and nitrous oxide emissions from a rice paddy from Tai Lake plain, China. Agr Ecosyst Environ 139:469-475

42. Zhang J, Hang X, Lamine SM, Jiang Y, Afreh D, Qian H, Feng X, Zheng C, Deng A, Song Z, Zhang W (2017) Interactive effects of straw incorporation and tillage on crop yield and greenhouse gas emissions in double rice cropping system. Agr Ecosyst Environ 250:37-43

43. Thammasom N, Vityakon P, Lawongsa P, Saenjan P (2016) Biochar and rice straw have different effects on soil productivity, greenhouse gas emission and carbon sequestration in Northeast Thailand paddy soil. Agric Nat Resour 50:192-198

44. Agegnehu G, Srivastava AK, Bird MI (2017) The role of biochar and biochar-compost in improving soil quality and crop performance: a review. Appl Soil Ecol 119:156-170

45. Tan Z, Lin CSK, Ji X, Rainey TJ (2017) Returning biochar to fields: a review. Appl Soil Ecol 116:1-11

46. Burrell LD, Zehetner F, Rampazzo N, Wimmer B, Soja G (2016) Longterm effects of biochar on soil physical properties. Geoderma 282:96-102

47. Głąb T, Palmowska J, Zaleski T, Gondek K (2016) Effect of biochar application on soil hydrological properties and physical quality of sandy soil. Geoderma 281:11-20

48. Major J, Rondon M, Molina D (2010) Maize yield and nutrition during 4 years after biochar application to a Colombian savanna oxisol. Plant Soil 333:117-128

49. Hardie M, Clothier B, Bound S, Oliver G, Close D (2014) Does biochar influence soil physical properties and soil water availability? Plant Soil 376:347-361

50. Bass AM, Bird MI, Kay G, Muirhead B (2016) Soil properties, greenhouse gas emissions and crop yield under compost, biochar and co-composted biochar in two tropical agronomic systems. Sci Total Environ 550:459-470

51. Peng X, Zhu QH, Xie ZB, Darboux F, Holden NM (2016) The impact of manure, straw and biochar amendments on aggregation and erosion in hillslope Ultisol. CATENA 138:30-37

52. Blanco-Canqui H (2017) Biochar and soil physical properties. Soil Sci Soc Am J 81:687-711

53. Butterly CR, Baldock JA, Xu JM, Tang CX (2010) Is the alkalinity within agricultural residues soluble. Molecular Environmental Soil Science at the Interfaces in the Earth's Critical Zone. 314-316

54. Martinsen V, Alling V, Nurida NL, Mulder J, Hale SE, Ritz C, Rutherford DW, Heikens A, Breedveld GD, Cornelissen G (2015) pH effects of the addition of three biochars to acidic Indonesian mineral soils. Soil Sci Plant Nutr 61:821-834

55. He LI, Zhong ZK, Yang HM (2017) Effects on soil quality of biochar and straw amendment in conjunction with chemical fertilizers. J Integr Agric 16:704-712

56. Xia Y, Zhang M, Tsang DCW, Geng N, Lu D, Zhu L, Igalavithana AD, Dissanayake PD, Rinklebe J, Yang X, Ok YS (2020) Recent advances in control technologies for non-point source pollution with nitrogen and phosphorous from agricultural runoff: current practices and future prospects. Appl Biol Chem 63:8

57. Luyima D, Sung JK, Lee JH, Woo SA, Park SJ, Oh TK (2020) Sorption of urea hydrogen peroxide by co-pyrolysed bone meal and cow dung slowed-down phosphorus and nitrogen releases but boosted agronomic efficiency. Appl Biol Chem 63:52

58. Signor D, Cerri CEO, Conant R (2013) $\mathrm{N}_{2} \mathrm{O}$ emissions due to nitrogen fertilizer application in two regions of sugarcane cultivation in Brazil. Environ Res Lett. 8:015013

59. Agegnehu G, Bass AM, Nelson PN, Bird MI (2016) Benefits of biochar, compost and biochar-compost for soil quality, maize yield and greenhouse gas emissions in a tropical agricultural soil. Sci Total Environ 543:295-306

60. Qin X, Li Y, Wang H, Liu C, Li J, Wan Y, Gao Q, Fan F, Liao Y (2016) Long-term effect of biochar application on yield-scaled greenhouse gas emission in a rice paddy cropping system: a four-year case study in south China. Sci Total Environ 569-570:1390-1401

61. Cui YF, Meng J, Wang QX, Zhang WM, Cheng XY, Chen WF (2017) Effects of straw and biochar addition on soil nitrogen, carbon, and super rice yield in cold waterlogged paddy soils of North China. J Integr Agric 16:1064-1074

62. Shen J, Tang H, Liu J, Wang C, Li Y, Ge T, Jones DL, Wu J (2014) Contrasting effects of straw and straw-derived biochar amendments on greenhouse gas emissions within double rice cropping systems. Agr Ecosyst Environ 188:264-274

63. Mukherjee A, Lal R, Zimmerman AR (2014) Effects of biochar and other amendments on the physical properties and greenhouse gas emissions of an artificially degraded soil. Sci Total Environ 487:26-36

64. Troy SM, Lawlor PG, Flynn CJ, Healy MG (2013) Impact of biochar addition to soil on greenhouse gas emissions following pig manure application. Soil Biol Biochem 60:173-181

65. Karhu K, Mattila T, Bergström I, Regina K (2011) Biochar addition to agricultural soil increased $\mathrm{CH}_{4}$ uptake and water holding capacity-Results from a short-term pilot field study. Agr Ecosyst Environ 140:309-313

66. Khan S, Chao C, Waqas M, Arp HPH, Zhu YG (2013) Sewage sludge biochar influence upon rice (Oryza sativa L.) yield, metal bioaccumulation and greenhouse gas emissions from acidic paddy soil. Environ Sci Technol 47:8624-8632

67. Hwang HY, Kim SH, Kim MS, Park SJ, Lee CH (2020) Co-composting of chicken manure with organic wastes: characterization of gases emissions and compost quality. Appl Biol Chem 63:3

68. Song HJ, Lee JH, Jeong HC, Choi EJ, Oh TK, Hong CO, Kim PJ (2019) Effect of straw incorporation on methane emission in rice paddy: conversion factor and smart straw management. Appl Biol Chem 62:70

69. Yanai Y, Toyota K, Okazaki M (2007) Effects of charcoal addition on $\mathrm{N}_{2} \mathrm{O}$ emissions from soil resulting from rewetting air-dried soil in short-term laboratory experiments. Soil Sci Plant Nutr 53:181-188

\section{Publisher's Note}

Springer Nature remains neutral with regard to jurisdictional claims in published maps and institutional affiliations.

\section{Submit your manuscript to a SpringerOpen ${ }^{\circ}$ journal and benefit from:}

- Convenient online submission

- Rigorous peer review

- Open access: articles freely available online

- High visibility within the field

Retaining the copyright to your article

Submit your next manuscript at springeropen.com 